\title{
Jansenist Women Negotiate the Pauline
} Interdiction

The Case of the Would-Be Nun, Marie-Catherine Homassel Hecquet

Religieuses et laïques jansénistes aux prises avec l'interdiction de Saint Paul : le cas de Marie-Catherine Homassel Hecquet

Thomas M. Carr Jr.

\section{(2) OpenEdition}

\section{Journals}

Electronic version

URL: http://journals.openedition.org/aes/743

DOI: $10.4000 /$ aes. 743

ISSN: 2258-093X

\section{Publisher}

Laboratoire LISAA

\section{Electronic reference}

Thomas M. Carr Jr., « Jansenist Women Negotiate the Pauline Interdiction », Arts et Savoirs [Online], 6 | 2016, Online since 12 July 2016, connection on 04 May 2019. URL : http://journals.openedition.org/ aes/743; DOI : 10.4000/aes.743

This text was automatically generated on 4 May 2019.

Centre de recherche LISAA (Littératures SAvoirs et Arts) 


\title{
Jansenist Women Negotiate the Pauline Interdiction
}

\author{
The Case of the Would-Be Nun, Marie-Catherine Homassel Hecquet \\ Religieuses et laïques jansénistes aux prises avec l'interdiction de Saint Paul : le \\ cas de Marie-Catherine Homassel Hecquet
}

Thomas M. Carr Jr.

1 In May 1708, the bishop of Amiens interrogated a twenty-one-year old woman MarieCatherine Homassel who was returning with her father from Paris to her home in Abbeville about her ties to Jansenism. He showed her a picture of a cleric, and professed astonishment when she claimed not to recognize him: "C'est de Mr [Antoine] Arnault reprit-il, le chef des jansénistes, et il n'est pas possible que tu ne le connaisses." ${ }^{1}$ He then demanded that she sign a document condemning Arnauld, Pierre Nicole and Cornelius Jansen in order to prove she was not a heretic. She replied that she would gladly sign the creed, but that since she had only heard good things spoken about the three men he named, she could not sign any blanket condemnation. She would sign a condemnation of propositions the Church condemned, but refused to attribute them to the Jansenists. She claimed not to be familiar with the theological disputes involved and invoked her conscience: "Je ne connais point Mr Arnauld, lui répondis-je, et ne sais pas qui il est, mais tel qu'il puisse être, avec la grâce de Dieu, ni son exemple ni son commandement ne me ferait jamais une chose contre ma conscience." (p. 126)

Despite her protestations of ignorance, the bishop had good reason to be suspicious. The distinction the young woman drew in agreeing to condemn propositions the Church condemned, but refusing to attribute them to Jansen, was exactly the one used by the nuns of Port-Royal in the formulary disputes in the 1660s. In a 1653 papal bull, Innocent X had condemned five propositions on grace, predestination, and sin that supposedly summed up the doctrine found in Jansen's 1640 posthumous Latin treatise, Augustinus. However, only one of the propositions could be found textually in the book. Jansenist leaders had sought a compromise that recognized the Church's authority to condemn 
heresy; the propositions were ambiguous enough that the Jansenists claimed that one could condemn them and thus affirm the church's teaching authority, while refusing to admit that the propositions adequately represented Jansen's views: in their eyes, the church was not condemning Jansen when it condemned the five propositions. The bishop was probably not surprised that the young woman invoked this same droit/fait distinction used by the Port-Royal nuns since she had been testing her vocation in the Parisian Benedictine convent of Liesse, whose abbess, Marie-Angélique Hébert, had been a boarding student at Port-Royal and was a great niece by marriage of Antoine Arnauld.

Although Marie-Catherine Homassel (1686-1764) remained out of the public eye, the range of her interests and her multiple spheres of activity make her an exemplar of the tensions surrounding learning and gender among Jansenist women. Her only published work during her lifetime was a short 1755 book about a feral girl found in 1731 near Châlons-en-Champagne. Many intellectuals of the time commented on the moral, scientific, and theological issues raised by the case - Voltaire, La Mettrie, Louis Racine and it continues to attract interest ${ }^{2}$. Homassel also wrote a biography of the aunt who raised her which was only published in 1862 and was republished in $2008^{3}$. In addition, family letters have been preserved in the Archives Nationales, and manuscript accounts of the persecutions she endured as a Jansenist are found in at least two libraries in France. Her father was a self-made entrepreneur who ran a successful enterprise in Abbeville that manufactured upholstery material. When her mother died, he sent her to Paris to be raised by a widowed aunt who was pious, but not a Jansenist. He largely ignored her until all his sons died, and he had no heir for his business. Despite MarieCatherine's desire to become a nun, he pried her out of the convent with the bishop's help, and eventually coerced her into marriage. She seems to have become - or one might say - realized she was a Jansenist only when accused of being one ${ }^{4}$. She suffered for her opposition, without her case attracting public notice; she believed in the miracles attributed to the Jansenist saint François de Pâris, without being a convulsionary. She would go on to have six children whom she sought to raise as Jansenists, and even won over her father in his old age. She was a strong-willed wife who obtained a financial separation from her husband when his drinking and gambling threatened her children's future. A voracious reader who educated herself on theological issues, she kept abreast of current events by reading gazettes. When she died in 1764, she possessed a large enough library that a bookseller had to be brought in to appraise it: a total of 455 volumes valued at 345 livres. Almost all are religious, but do include Prévost's Histoire générale des voyages, and a title I decipher as the Journal des savants ${ }^{5}$. Her intellectual interests were wideranging, even if she saw all issues through the lens of her militant Jansenism.

In order to illustrate Homassel's use of theological learning, I will use two kinds of "I" documents: professions of orthodoxy and debates contained in first-person accounts of persecution. Since both were practiced ably by Jansenist nuns and since Homassel modeled herself on such nuns, I will first show how nuns used these genres: first, the seventeenth-century Port-Royal nuns who only reluctantly agreed to the formulary under pressure from Antoine Arnauld; then eighteenth-century ones who refused to accept Clement XI's condemnation of Pasquier Quesnel in the 1713 papal bull Unigenitus ${ }^{6}$.

5 Women's relation to theological learning was constrained by the restrictions based on the common interpretation of I Timothy 2 11-12 where Paul had written, "Que les femmes se tiennent en silence et dans une entière soumission lorsqu'on les instruit. Je ne permets point aux femmes d'enseigner... mais je leur ordonne de demeurer dans le silence." 
According to this view, women were excluded from the clergy and from public declarations on religion; whether nuns or lay, they were also expected to eschew theology proper and concentrate on devotional practices that were more affective than intellectual, more practical than dogmatic. As one eighteenth-century Ursuline nun described her reading before her theological awakening as a Jansenist: “J'avais passé les temps qui avaient précédé et qui étaient mes premières années de religion dans la lecture des livres de morale par de bons auteurs sur la vie chrétienne et religieuse." (CSR, (p. 272)

6 The Pauline prohibition seemed to be especially convenient to the nuns of Port-Royal in the 1660s. They used the droit/fait distinction when refusing to sign the formulary condemning the five propositions as summarizing Jansen's stance. The abbess, Agnès Arnauld, a sister of Antoine Arnauld, insisted that the nuns had been isolated from discussion of the contested issues. Moreover, they were unable to read Jansen's Latin treatise to determine for themselves if it contained the condemned propositions. But since they had heard much good spoken of the Flemish bishop, they could not unreservedly in conscience swear to the question of fact. However, the abbess's claim was not entirely true. A handful of nuns, probably no more than five or six, the intellectuals among them, had followed the theological debate and a couple had likely at least dipped into the Latin Augustinus, including Blaise Pascal's sister Jacqueline, and a niece of the abbess and future abbess herself, Angélique de Saint-Jean Arnauld d'Andilly. ${ }^{9}$ Pierre Nicole is said to have described her as "naturellement un peu scientifique"10. This reference to her "scientific" expertise refers to a taste for abstract, learned questions and argumentative tendencies that were not suitable for women in general, and even less for nuns. Angélique de Saint-Jean's learned intransigence would, in fact, create problems, when in 1668 the male Jansenist leaders sought a face saving compromise with the church, by which the nuns would formally agree to both parts of the formulary, while adding restrictive clauses dealing with the fact issue.

7 The professions of faith that the Port-Royal nuns produced took the form of collective "we" declarations concerning their stance on the formulary which they drew up after deliberation among themselves during chapter meetings and which each nun signed one after another. These declarations were presented to representatives of the archbishop of Paris, and quickly circulated, sometimes in print, among supporters of the nuns. The declarations walk a thin line between the humble stance of nuns respectful of authority and the defiance that their refusal to accept the formulary embodies. For example, on July 5,1664 , the nuns signed a lengthy statement setting forth their reasons for noncompliance. In the following extract, they justify their respectful refusal with two of their key arguments - an appeal to conscience and their submission as nuns to the Pauline interdiction, as seen in their ignorance of the facts of the case. Respectful of the interdictions, they have not looked into the fait issue themselves:

Mais après tout ce qu'ils nous ont dit, nous n'avons pu vaincre la répugnance de notre conscience, qui nous persuade toujours que ne sachant point si les hérésies condamnées sont dans le livre d'un évêque catholique que nous sommes incapables de lire, nous sommes incapables aussi de rendre témoignage par une signature publique de ce fait que nous savons être contesté entre des théologiens, et dont par notre état et notre profession nous ne sommes point obligées de nous informer. ${ }^{11}$

8 The nuns are much less concerned with observing the Pauline interdiction in the other set of "I" documents - their captivity narrations. In August 1664, the archbishop Hardouin de Beaumont de Péréfixe had twelve Port-Royal nuns who were considered the 
ringleaders arrested and moved to other Parisian convents where they were isolated in hope of breaking down their resistance. Upon their release, they wrote up their experience of imprisonment at the suggestion of the male Jansenist leaders. Within these memoirs, I highlight the interviews they recount with emissaries sent to "convert" them; in some cases, their opponent was the archbishop himself. These self-reported debates allow the nuns to display their own theological prowess in action. Angélique de SaintJean's are the most famous ${ }^{12}$. She expresses her dismay at the lack of theological knowledge of a lay woman, Madame de Rantzau (p. 56-60), sent to dispute with her and of the nuns in convent in which she is held. An even greater satisfaction comes from holding her own against the archbishop himself. She has the pleasure of hearing him acknowledge her expertise: he flatters her by saying that with her he can use technical distinctions, such as the one between being formally and materially a heretic: "vous qui êtes savantes, vous entendez bien ces termes". (p. 51) She notes as well that he was incapable of producing any new arguments in favor of the formulary. (p. 49)

The problems with unruly Jansenist nuns should have been over when Unigenitus was promulgated in 1713. Louis XIV had destroyed the monastery of Port-Royal and dispersed its nuns. However, Jansenist tendencies had spread among the laity, male clergy, and nuns. Instead of condemning abstract propositions that were said to sum up the errors of a theological treatise, Clement XI condemned 101 quotations taken directly from a popular devotional text written in French, the Réflexions morales sur le nouveau testament of Pasquier Quesnel. The strategy of resistance could thus no longer be the droit/fait distinction. Instead, Jansenists appealed over the pope's head to a hypothetical general council of the whole church. While waiting for the council to convene to hear the appeal, the bull would be suspended. Officially, the appeal was made by an ever dwindling minority of the French episcopate. Clerics and laypeople could support this appeal by the bishops by filing their adhesion to the appeal in various forums.

Given the fact that the Port-Royal nuns had been a focal point of resistance to the formulary in the seventeenth century, it is not surprising that women became a target of a proposition condemned by Unigenitus. One of the most important goals of the Jansenist movement was to extend access to all the faithful to the tools of spiritual life, including scripture and liturgical texts, instead of reserving such "primary texts" to male clerics with theological training. Thus the messieurs de Port-Royal had translated the mass and the Bible, and Quesnel had insisted that all Christians, including women, incorporate scripture into their devotions ${ }^{13}$. The $83^{\text {rd }}$ condemned proposition in Quesnel's book had defended women's access to scripture. He had written: “C'est une illusion de s'imaginer que la connaissance des mystères de la religion ne doive pas être communiquée à ce sexe par la lecture des Livres Saints.... Ce n'est pas de la simplicité des femmes, mais de la science orgueilleuse des hommes qu'est venu l'abus des Écritures et que sont nées les hérésies." ${ }^{14}$ By stigmatizing this statement, the bull suggested that female access to scripture encouraged the birth of heresies ${ }^{15}$.

11 Supporters of Unigenitus were quick to discredit the appeal movement by identifying it with the damage caused by unruly women. In 1715, the Jesuit Gabriel Daniel published an anti-Jansenist text he had written some ten years earlier that targeted women's propensity to encourage heresy in their discussions. His Lettre à une dame de qualité où l'on examine jusqu'à quel point il est permis aux dames de raisonner sur les matières de religion (Paris, L. Coignard, 1715) was moderate, however, in comparison with the ridicule another Jesuit, Guillaume-Hyacinthe Bougeant, heaped on Jansenist women who dared to meddle in 
theology in his parody of Molière's Les Femmes savantes entitled La Femme docteur ou la théologie tombée en quenouille (Liège, Veuve Procureur, 1730). The play went through multiple editions and was performed in some private homes and colleges. Bougeant followed up in 1731, 1732, and 1733 with sequels ${ }^{16}$. A third Jesuit, le père Le Fèvre, preached that it was not permissible for women to discuss religion and that several heresies were born from their conversations in a sermon in the Parisian church of SaintLouis-dans- l'Ile in spring $1734^{17}$. One of the most energetic enemies of the Jansenists in the French episcopate, Jean-Joseph Languet de Gergy (1677-1753), bishop of Soissons and later archbishop of Sens, complained that in opposing the bull, women had learned to engage in such unseemly activities as to "disputer... s'élever contre l'autorité légitime ... être des raisonneurs"18. His own preferred model was the Visitantine nun, MargueriteMarie Alacoque, whose biography he wrote; her visions were a source of the nonliturgical cult of the Sacred Heart, of which he was a fervent promoter.

The leaders of the Jansenist appeal were much more interested in gathering public support from male clergy who had standing to make such an appeal than enlisting nuns. While the number of nuns who signed a formal appeal was small, there was resistance in many convents ${ }^{19}$. The position of such nuns was particularly vulnerable: trapped by their vows and cloister, they could not flee when church authorities demanded submission, as male clerics or lay persons could do. Both church and royal authorities were determined to crush opposition, and although the mechanisms of enforcing conformity took decades to put effectively in place, they moved inexorably. The Jansenist leaders, who could seldom protect the nuns from bishops and confessors who demanded submission to Unigenitus, had to at least provide the inmates of convents moral support. In the 1720 s and 1730s, nuns turned to two hold-out bishops, Charles-Joachim Colbert de Croissy (1667-1738) of Montpellier and Jean Soanen (1647-1740) of Senez for advice, comfort, and reassurance.

The stance of the nuns had also shifted. The Port-Royal abbess claimed to have shielded her nuns from the theological disputes, and Homassel in 1708 claimed that such had been the case at Liesse. After Unigenitus, nuns felt it their duty to keep abreast of "the affairs of the day". A novice mistress wrote in 1737 that she taught her charges in a general way about the disputes and thought she should have them read the bull itself (CSR, (p. 98). Other nuns report that they continued to read the condemned book of Quesnel (c(p. CSR, (p. 165, 187). In none of these cases did either bishop discourage access by nuns to the controversies. Rather, the bishops saw being well informed as the best way to defend what the Jansenists called "les verités de la grâce." The shift can also be seen in the debates with church authorities that nuns reported to Colbert and Soanen. In 1726, a priest accused a Carmelite novice of acting like a doctor of the church: "Vous êtes vousmême un docteur, un père de l'Eglise, l'Augustin de nos jours, il ne vous manque plus que le bonnet." Her stance was that all one needed was "un peu de sens commun ... pour distinguer l'erreur de la vérité" (CSR, (p. 318). The issue was not whether the condemned propositions were or were not in a book; anyone who could read French could determine that. Now the content of the condemned propositions was openly discussed. The playing field had changed from the fait to the droit ${ }^{20}$.

The function and nature of the nuns' professions of orthodox faith shifted as well. The Port-Royal nuns had been responding to specific demands for their adhesion from competent ecclesiastical authorities. The documents nuns sent to Colbert and Soanen had no legal status. They were spiritual testaments by which the nuns solemnly, but privately, 
declared their allegiance. The nuns were often fearful that on their deathbed, submission would be extorted from them in return for access to the last sacraments and burial rites. These professions of faith could take many forms and offered the nuns a space to display their theological knowledge as they enumerated their beliefs and reasons for rejecting Unigenitus. Françoise de Noirefontaine gives five examples, and here I have only space to note the bishops' response. Colbert and Soanen preferred that the nuns' statements be brief and avoid theology. In 1739, Soanen chided one nun of the Visitation order: "On n'est pas surpris de voir une fille instruite; mais on goûte rarement qu'elle se montre théologienne. Votre acte, ma très chère fille a des beautés qui paraissent empruntées aux personnes qui ne connaitront pas vos lumières.... j'impute à son élévation le défaut de subscriptions." He thus suggested that she would have obtained more signatures from sister nuns in her convent had she stuck to basics (CSR, (p. 107, 204).

In fact, despite the Jansenist leaders' insistence that women have equal access to scripture with men as a source of spiritual interiority, they shared the reservations of proponents of Unigenitus about women becoming theologically learned. Even Quesnel, in defending his eighty-third condemned proposition, protested that he had never proposed that women become "savantes":

On ne trouvera rien dans le livre des Réflexions qui favorise dans les femmes l'ambition d'acquérir le nom de savantes, ni même de le devenir. Au contraire, j'ai averti celles qui se mêlent de juger et de décider des choses de la religion d'apprendre (de l'Apôtre [Paul]) à se renfermer dans le silence que l'esprit de Dieu leur impose à cet égard. Heureuse condition, dis-je ailleurs, de trouver dans son état et dans son devoir l'inestimable avantage de ne se point produire au dehors, et de ne prêcher que par l'amour et la pratique du silence, de l'humilité, de l'obéissance, de la dépendance et par la bonne odeur des vertus chrétiennes. ${ }^{21}$

His patronizing attitude sums up the gender bind the nuns found themselves in. The eighteenth-century Jansenist bishops did not dissuade the nuns from familiarizing themselves with the theological issues; they knew that the better informed the nuns were, the stronger their resistance would be. Yet as women, as nuns, this resistance should not be cast as formal theological argumentation. Be knowledgeable, but keep your knowledge to yourself, even in these professions of faith that were not meant to be made public, was the message. Theological dispute should be left to men.

I will now turn to how this gender bind played out in the life of a laywoman, albeit, one who at one time aspired to a life as a nun. Marie-Catherine left various texts that recount the first fifty years of her spiritual life. Her biography of the aunt who raised her covers her own life up to age twelve; her first "relation de captivité" entitled "Vexations au sujet du formulaire" extends to her marriage in 1710; a second one, "Vexations au sujet de la constitution" goes up to about age fifty. Both of these last two contain accounts of debates, the first with the bishop of Amiens in 1708 that I began with; the second, with her pastor in Abbeville in 1736. In each, she believes she has won at least a moral victory. In the first in 1708, she presents herself as being at a disadvantage in terms of theological knowledge: a bishop against a young woman who claims not to master the theological issues; but she is confident that she has the moral high ground, and resists as long as possible. By 1736 , she was fully informed theologically. Even when she claims ignorance, she cites the history of Arianism, and it is clear that she is at least the equal of her local pastor as a controversialist. She has become, if not a theologian, a learned apologist for Jansenism: 
CURÉ : Y pensez-vous de parler comme cela des évêques, de vos supérieurs? À vous entendre, ce sont des hérétiques, des gens qui veulent détruire la religion, et vous êtes plus éclairée qu'eux tous.

Homassel : Je ne dis pas qu'ils veulent la détruire, mais qu'ils sont hommes, et par conséquent capables d'être trompés et séduits sans qu'ils le veuillent; au reste, Monsieur, je n'ai pas la présomption de me croire plus éclairée qu'eux ; au contraire, c'est parce que je me crois ignorante, mais en même temps par la grâce de Dieu fort attachée à ma religion que j'ai peur de tout ce qui pourrait y donner atteinte : ainsi il me suffit que je voie dans les propositions ce que l'évangile, le Credo et mon catéchisme m'ont appris pour que j'aie une horreur invincible pour un décret qui le condamne. Il me suffit que je voie et n'entende dans ces propositions que la toute-puissance de Dieu; le besoin que nous avons de la grâce pour pratiquer le bien ; l'obligation de l'aimer pardessus toutes choses; de lui rapporter toutes nos actions, de faire toujours notre devoir au risque de tous les maux qui en peuvent arriver; en un mot les mêmes choses que l'Église a toujours crues et enseignées depuis J.-C. pour que je me garde bien de condamner son langage. Je l'entends et je le crois comme nos pères l'ont entendu et $\mathrm{cru}$; je suis trop simple et trop ignorante pour aller plus loin.

CuRÉ: Quel entêtement ! Mais qui vous a dit que la Bulle condamne toutes ces vérités?

Homassel: La Bulle elle-même; il n’y a qu'à la lire.

CURÉ: Eh! Non, encore une fois ce n'est rien de tout cela qu'elle condamne; vraiment ce sont là les vérités de la religion et je mourrais pour les soutenir: mais c'est un mauvais sens qui est caché dans les propositions que la Bulle condamne.

Homassel: La Bulle ne dit pas cela, Monsieur, et qui plus est, défend de parler, de penser autrement qu'elle; mais si, comme vous le dites, on ne doit condamner que le mauvais sens caché, je signerai, si vous voulez que respectant les paroles et la doctrine catholique que me présentent d'abord les propositions du Père Quesnel, je ne condamne avec la Bulle que le mauvais sens et les interprétations hérétiques qu'on peut lui donner.

CuRÉ: Cela suffirait dans un sens, mais on ne serait pas content d'une telle signature; ce serait marquer de la défiance et faire injure au Pape.

Homassel : Mais si on n'est pas content, Monsieur, que je condamne seulement le mauvais sens qu'on dit caché dans les propositions, et qu'on refuse ma signature à moins que je ne condamne aussi les paroles que vous convenez contenir et exprimer les vérités de la religion. Ce refus m'est bien suspect et me ferait volontiers croire que les auteurs de la Bulle, bien loin de vouloir s'assurer par là de la foi des fidèles, ont envie de la leur faire renoncer. Tenez, Monsieur, je suis ignorante et toute ma science se borne à l'évangile qui m'ordonne d'obéir à l'Église, et l'histoire de l'Église m'a appris ce qu'elle demande à ses enfants. Permettez-moi de vous demander si elle a jamais obligé les Ariens même ou ceux qu'elle soupçonnait de l'être, de condamner les paroles de l'Évangile, sur lesquelles les hérétiques croyaient prouver leurs erreurs ${ }^{22}$.

Much more intimate than such confrontations with church authorities are the professions of faith that mark crossroads in her life. We know of five $(1696,1708,1732$, $1736,1754)$, of which the last three survive. The first is in many ways the fountainhead of the others. It was written as the culmination of her preparation for her first communion at age ten in 1696. She was instructed by her aunt Michelle Homassel with whom she lived, under the direction of her aunt's spiritual advisor. At the time, there was no way of knowing the role this director, Jean Soanen, would play in Marie-Catherine's career as a 
Jansenist. In 1696, Soanen was an Oratorian conforming court preacher who had distanced himself from Jansenism. In fact, Louis XIV had nominated him for bishopric of Senez on this basis in 1695. Marie-Catherine notes that her preparation for this communion was unique. Instead of attending the catechism classes organized in her parish for girls, she read the Bible and church fathers privately. This method gave her from childhood a much deeper knowledge that that of the average girl and one that was based on primary sources. Two weeks before the communion, her aunt had her write "une espèce de profession de foi de tout ce que je pensais et croyais sur toutes les principales vérités et en particulier sur le mystère de l'Eucharistie" that was submitted to Soanen so that he could judge if the girl was sufficiently instructed. ${ }^{23}$ This proof of the purity of her faith, written long before she was accused of heresy, likely became the model for subsequent attempts to testify to her orthodoxy.

This was certainly the case of the second one, which was written under more stressful circumstances. In 1708, shortly after her interviews with Sabatier when she signed the formulary and soon after retracted her signature, she fell ill. "Ne voulant laisser aucun doute de la pureté de ma foi, j'écrivis une profession de foi pour lui être envoyée après ma mort." ${ }^{24}$ However, this 1708 text took on a role beyond that of testimony addressed to others. It became a way to reassure herself that she had remained faithful to the lessons learned from her aunt. Of the 1708 profession she said, "Je m'en sers de temps en temps pour m'affermir et me rassurer contre tous les reproches qu'on m'a faits."

This 1708 profession has not survived, but Homassel reports that it forms the basis of the 1736 one $^{25}$. In fact, the text of 1732 , one which has also survived, follows closely that of 1736, so that all three are linked. The two professions of faith surviving from the $1730 \mathrm{~s}$ are largely generic in that they are inspired by creedal statements like the Nicene Creed and catechism texts. They open with the standard doctrine about the Trinity, move on to the church and close with the seven sacraments. The goal is to prove the Jansenists' contention that they were not heretics like Protestants, but accepted traditional Catholic teaching. Nonetheless, from time to time, Homassel interjects a Jansenist gloss on the creeds, as when she discusses for whom Christ died in the 1732 one, or when she explains how the Jansenist interpretation of efficacious grace can be reconciled with free will in the 1736 one. ${ }^{26}$ Jansenism was a many-layered theological movement whose center of gravity shifted, but the controversies over grace and contrition were the original bone of contention. She shows her awareness of the fundamental theological issues and her mastery of the arguments on both sides. However, on the whole, these two professions of faith steer clear of detailed theological argument, as if she knew that Jansenist leaders like Soanen, to whom the 1736 one is addressed, preferred this stance in women.

All three of the surviving professions were occasioned by crises in her life or linked to measures taken against Jansenists. In early 1732, there had been incidents of convulsionism in Abbeville; while there is no evidence that Marie-Catherine took part, during the repression that followed, known Jansenists like her were threatened. She knew that other Jansenists had been refused the last sacraments, and thus wanted to leave a testimony of her true beliefs in case she suffered such deathbed excommunication. During the first part of 1736, the stress was more personal. Turning fifty sparked a period of self-doubt that was heightened by losing her two oldest daughters who left Abbeville to marry Parisian merchants and residual guilt for having signed the formulary. In a search for reassurance, she tried to reestablish contact with Soanen whom she had last seen in 1705 . This childhood link adds a personal dimension 
not present in the letters sent him by nuns collected by Françoise de Noirefontaine. In the meantime, he had become the focal point of the appeal of Unigenitus and a Jansenist martyr after his deposition as bishop of Senez in 1727 and exile to the abbey of La ChaiseDieu in Auvergne. The eighty-nine- year-old bishop reassured her in his reply that she had expiated a fault that he himself was guilty of (he had signed the formulary as well), while enjoining her to remain vigilant in the future:

Que vous êtes heureuse, ma très chère fille, d'avoir essuyé par vos larmes une faute que je ne cesse de pleurer dans ma solitude! Le repentir sincère que vous témoignez de la signature pure et simple du formulaire que l'on vous a extorquée malgré vous, ne laisse plus subsister devant le Seigneur cette cédule de mort qui vous était contraire; mais souvenez-vous toujours que vous avez été surprise, afin que la connaissance de votre faiblesse devienne le principe d'un courage plus généreux. ${ }^{27}$

The October 24, 1754 profession of faith is much longer and more interesting as Jansenist apologetics. It was written during the billet de confession controversy when again Homassel felt threatened by refusal of the last sacraments and Christian burial. She no longer uses the creeds of the early church as a framework. After all, there was no disagreement over the doctrine of the Trinity that they had been meant to settle. Instead, she focuses on the nature of the church itself, specifically, its teaching authority. Her challenge was to reconcile her attachment to an institution that she accepted as catholic, apostolic, and Roman, while rejecting a papal bull. The rationale she sets forth is in line with the conciliar arguments of Jansenist theologians. It is organized around a distinction between the Church of Rome, which she accepts, and the Roman or papal court that she sees a corrupt tool of the Jesuits and which she ultimately depicts as the Beast of the Apocalypse. While her arguments are standard among Jansenists, she casts them very personally as a debate in which she refutes the arguments proposed to her one after the other by the supporters of Unigenitus. Thus she incorporates into her last profession of faith the same sort of disputation that she had had with her bishop in 1708 and her pastor in 1736 and projects the same confidence that she has won them.

She again admits that her theological knowledge has limits. One of the arguments she refutes is that she is unable to give a complete accounting for her stance: "J'avoue que je ne suis pas capable, ainsi qu'on me l'a reproché plusieurs fois, de démêler et dire toutes les raisons [for her opposition to the bull]." She is even willing to attribute this failure to "cette incapacité ordinaire à mon sexe." Her response is that the faithful are not required to give a full theological accounting for their beliefs. Simply recognizing that a teaching is contrary to the plain sense of the faith is enough: "Nous ne sommes pas obligés d'être assez savants pour pouvoir répondre à toutes les difficultés." 28 This gesture toward the rhetoric of female humility does not prevent the reader from recognizing Homassel's essential mastery of the issues that goes well beyond the catechism.

In the 1732 and 1754 professions she also takes a stand on two Jansenist issues that were not dogmatic as such: the healings and miracles that took place at the tomb of the Jansenist holy man, François de Pâris, at his tomb in the Saint-Medard cemetery beginning in 1727, and the convulsions that began among Jansenists in 1731. Most Jansenists agreed that the cures demonstrated divine approval of their cause. It was inconceivable to them that God would produce a miraculous healing when the deacon Pâris's intervention had been invoked if he were indeed a renegade, as the official church maintained. She adduces these miracles in 1732 against Unigenitus. In fact, she says she has witnessed them. Although the phenomenon known as the convulsions had already begun when she signed her 1732 profession, she does not mention them. These trances, 
shakings, accompanied by impromptu discourses and prophecies that began in the Saint Medard cemetery and continued in private homes were much more controversial among Jansenists. Some saw them as the continuation of the healing miracles; others were embarrassed by them, and thought they were the product of illusion, if not fraud. While she says she witnessed early ones that took place in the cemetery, she does not mention participating in the later ones in private houses. In 1754, she sides with the centrist group of Jansenists who neither rejected them wholesale nor endorsed them without reservation. Instead, they had to be examined on a case by case basis with discernment. She is willing to attribute divine inspiration to the discourses pronounced during them. She describes such speechs, often delivered by women, as "des sentiments des lumières et même des interprétations du sens de l'écriture sainte ... qui surpassaient infiniment en précision, en clarté solide et onction tout ce que la science et l'étude humaine la plus profonde et la plus étendue ont pu faire dire ou écrire aux plus savants". (p. 20) Thus even in this profession of faith which displays her theological prowess as an apologist, she acknowledges a sacred wisdom, sometimes called the "sciences des saints" (although she does not use the term) that goes beyond learning acquired by study and which is available "à des simples, à des ignorants de tout état, de tout sexe, de tout âge" ${ }^{29}$. (p. 21)

In reviewing how these Jansenist women dealt with expectation stemming from Paul that their sex not engage in theology and remain in the private sphere, I will point to three issues: gender, learning, and self-portraiture.

First, the women's relation to the male Jansenist leaders changed. The Port-Royal nuns had worked closely with their male advisors and supporting bishops and ultimately acceded to pressure from them to agree to the compromise called the Peace of the Church in 1668. By the late 1720s, the appellant bishops could do little to protect Jansenist nuns who looked to them now primarily for reassurance and moral support. They were impotent fathers who could only exhort the nuns to continue to believe Jansenist doctrine while they suffered and resisted largely in silence and out of sight. As a laywoman, Homassel had more freedom of movement. When family affairs permitted, she moved to Paris where she was under less surveillance. Like the nuns, she sought Soanen's approval, but in her final profession of faith, written fourteen years after his death, she displayed more theological expertise than he approved of in women, all the while aligning herself with him in regard to the convulsions. Her 1730 professions of faith had been silent on them, even though her cousin, the famous Jansenist physician Philippe Hecquet, had rejected them as a natural phenomenon, as had Jacques-Joseph Duguet (1649-1733), the great Jansenist theologian whose books she owned. The stance she affirms in 1754 echoes Soanen's position that the convulsions had to be examined case by case.

The grounds of learning shifted between the formulary dispute to the Unigenitus controversy from the fait to the droit. The few Port-Royal nuns who probably had read the Latin treatise hid this fact, and the convent's official policy was based on the Pauline prohibition: it was not suitable for women to have read Jansen's Augustinus and know whether it contained the condemned propositions. Unigenitus condemned propositions from a book written in French, many of which the Jansenist claimed came from the Fathers of the Church or even scripture. Now women discussed the content of the condemned propositions. They made great efforts to inform themselves on the issues. Jansenist women became learned to the extent that they were mocked in Bougeant's plays. Yet they remained tributary to the restrictions on female learning. Two 
expressions that appear frequently in the declarations of the eighteenth-century nuns are évidence and sens commun. The ridiculousness of Unigenitus was obvious to anyone who could read, they maintained. No great learning, only common sense, was required to reject the bull. This tactic might have been effective in discrediting Unigenitus, but it also reinforced the common interpretation of I Timothy 2 11-12 that women were not to be theologians: it was suitable for women to testify to their faith, but not to examine it intellectually. In fact, it was rare for Jansenist women to take their learning into print ${ }^{30}$. Perhaps the only Jansenist contemporary of Homassel to publish was Armande-Isabelle Duguet-Mol (1675-1753), the niece of Jacques-Joseph Duguet. However, her publications remain intra muros; her polemics are directed at other Jansenists who did not reject the convulsions as her uncle had; she aims more at defending her uncle than elucidating theological issues ${ }^{31}$. Homassel's one published book during her lifetime, the Histoire d'une jeune fille sauvage, is a work of circumstance, published to aid the wild girl. While it appealed to devout readers by testifying to the young woman's faith in divine providence, it also attracted intellectuals by speculating on her Eskimo origins. The learning it displays is entirely secular.

In this context where women were expected to eschew displays of formal theological learning, it is useful to see these debates and especially the professions of faith as spiritual self-portraits, portraiture being a more accepted female genre. One might object that reciting a formulaic profession of faith like the Apostles' Creed requires no theological expertise and seems on the surface almost the opposite of an intimate portrait. Such canonical creeds affirm dogmatic propositions that one accepts as a member of a group: they are an adhesion to a collective identity. However, the professions of faith of the Jansenist women allow scope for personalization ${ }^{32}$. The women pick and choose among available points of doctrine to express their most heartfelt beliefs. The professions are solemn declarations of what the women most want to be remembered for after their deaths. In the case of Homassel, she specifically targets her children and grandchildren. In her 1764 will, Homassel bequeathed the painted portrait of the pious aunt who had educated her to her only living daughter ${ }^{33}$. This portrait has been lost, but two of her professions of faith survive in the Archives Nationales because some of her children and grandchildren found them so compelling that they passed them from generation to generation in the family. In fact, neither the 1732 one nor the 1745 survive in holograph. The first was copied by her eldest daughter and the second by a granddaughter.

Despite Paul's injunction, despite her protestations of ignorance, Marie-Catherine became theologically "savante" as an apologist of Jansenism, even if she aligned herself largely on the positions of her hero Soanen. However, she remained tributary to Paul in that she avoided the public sphere and passed on her spiritual legacy in the form of witness in private textual self-portraits aimed first of all at her family. 


\section{NOTES}

1. Relation des vexations essuyées au sujet du formulaire, (p. 121. Copies are found in the Bibliothèque municipale de Lyon (SJ Ms 8/558) the Bibliothèque de la Société de Port-Royal (BO 875). I quote from the Port-Royal manuscript.

2. Histoire d'une jeune fille sauvage trouvée dans les bois à l'âge de dix ans. Paris, n.p., 1755. The most convenient overview that situates the case in terms of gender and other feral children is Julia V. Douthwaite, The Wild Girl, Natural Man, and the Monster: Dangerous Experiments in the Age of Enlightenment, Chicago, Chicago UP, 2002, (p. 29-53.

3. Nicolas Lyon-Caen's Un Roman bourgeois sous Louis XIV: Récits de vies marchandes et mobilité sociale: les itinéraires des Homassel, Limoges, Pulim, 2008 situates her life in father's career and reprints her biography of her aunt.

4. Thomas M. Carr, Jr., "The Quebec Hospitalière and the Closeted Jansenist: The DuplessisHecquet Correspondence, with an Unpublished Letter by Hecquet", Lumen: Select Proceedings from the Canadian Society for Eighteenth-Century Studies, 29, 2010, (p. 91-105.

5. Archives nationales, Minutier central, étude L, 502, October 20, 1764.

6. Examples for eighteenth-century nuns come from Françoise de Noirfontaine's Croire, souffrir et résister: Lettres de religieuses opposantes à la Bulle Unigenitus, Paris, Nolin, 2009, abbreviated as CSR.

7. Translation of Louis-Isaac Lemaître de Sacy dans la "Bible de Port-Royal".

8. Mita Choudhury's chapter "Martyrs into Citizens: Nuns and the Resistance to Unigenitus, 1730-1753" in Convents and Nuns in Eighteenth-Century French Politics and Culture, Ithaca, Cornell University Press, 2004, (p. 33-69 examines the gender bind in which women, and particularly nuns, found themselves in much more detail than is possible here, although she does not refer to the droit/fait distinction as I will. See also her "Gendered Models of Resistance: Jansenist Nuns and Unigenitus", Historical Reflections $\mathrm{n}^{\circ}$ 35, 2009, (p. 28-51.

9. Linda Timmermans, "La 'Religieuse parfaite' et la théologie: l'attitude de la Mère Agnès à l'égard de la participation aux controverses”, Chroniques de Port-Royal n 43, 1994, (p. 100-101. Daniella Kostroun, in her detailed study of the use of the Pauline interdictions in the internal debates among the nuns, points out that the fact that some nuns were more knowledgeable than others created a conflict between their collective identity as members of a community and their individual consciences. See especially (p. 117-140, in her Feminism, Absolutism, and Jansenism: Louis XIV and the Port-Royal Nuns, New York, Cambridge University Press, 2011.

10. Louis Racine, "Diverses particularités concernant Port-Royal recueillies par mon père de ses conversations avec M. Nicole" in the Abrégé de l'histoire de Port-Royal. A. Gazier ed., Paris, Société française d'imprimerie, 1908, (p. 202.

11. Relation de ce qui s'est passé à Port-Royal depuis le commencement de l'année 1664 jusqu'au jour de l'enlèvement des religieuses, qui fut le 26 août de la même année. n. p., n. d., (p. 60.

12. Angélique de Saint-Jean Arnauld d'Andilly, Aux portes des ténèbres: Relation de captivité, Paris, Table Ronde, 2005. Agnès Cousson thoroughly analyzes the tension in these captivity narratives, seen as "I" documents, between the Port-Royal's official stress on humility and its reluctance to enter into disputes with the immediate need to win sympathy and to strengthen the resolve of the community by focusing on Angélique de Saint-Jean: L'Écriture de soi: Lettres et récits autobiographiques des religieuses de Port-Royal, Paris, Honoré Champion, 2012, (p. 539-562.

13. Bernard Chédozeau, "Port-Royal et le jansénisme: la revendication d'une autre forme du tridentinisme", XVII Siècle, $\mathrm{n}^{\circ}$ 171, 1991, (p. 57-74. See Joseph Bergin, Church, Society and Religious 
Change in France, 1580-1730, New Haven, Yale University Press, 2009, (p. 414-417 for a discussion of Jansenist pastoral practices.

14. The condemned propositions are cited in an appendix of an early Jansenist attempt to refute the bull, Les Hexaples ou les six colonnes sur la constitution Unigenitus. Amsterdam: Gérard Kuiper, $1714,17$.

15. This misogyny must be placed in the larger context of the access of lay persons to scripture. As Bernard Chédozeau pointed out in a 1988 article, revised in 2012, women represented the lay person "par excellence." The competency of all lay people to read scripture in translation was questioned, with women considered the least comptent. He points out that that this position was disputed in France, and French Catholics had access to translations of the Bible when they were forbidden in Spain and Italy. "Aux sources éloignées de la Révolution: les laïcistes doctrinaux et la lecture de la Bible (xVIII ${ }^{\mathrm{e}}$ siècle)", Le Nouveau Testament autour de Port-Royal: traductions, commentaires et études (1697-fin du XVIII siècle), Paris, Champion, 2012, (p. 221-248.

16. See André Dabezies, "L'Érudition et l'humour: le père Bougeant (1690-1743)", Dix-huitième siècle, $\mathrm{n}^{\circ}$ 9, 1977, (p. 259-271 for an overview and assessment of Bougeant's life and plays.

17. The sermon is known through its refutation, La Lettre des dames de la paroisse Saint-Louis-dansl'Ile au révérend père Le Fèvre jésuite. n.p., 1734, which is more an anti-Jesuit tract than a defense of women's right to discuss religion. It concedes that questions of doctrine are beyond women's sphere: "Nous savons qu'il ne nous est pas permis de décider sur la religion", but insists that women should be able to confess their faith and share it with others : "Ne nous ôtez pas la liberté de confesser J-C de bouche, de parler comme si Dieu parlait lui-même, de tenir des discours propres à l'accroissement et l'édification de la foi" (p. 1-2.

18. Instruction de Mgr. J. Joseph Languet de Gergy, évêque de Soissons contenant un troisième avertissement à ceux qui dans son diocèse, se sont déclarés appelant de la constitution Unigenitus, Reims, Multeau le jeune, 1718, (p. 199-200 (article 94). Elizabeth Rapley gives examples of Languet's persecution of Jansenist nuns in her evenhanded account: "'Personae non gratae': Jansenist Nuns in the Wake of Unigenitus", A Social History of the Cloister: Daily Life in the Teaching Monasteries of the Old Regime, Montreal, McGill-Queen's University Press, 2001, (p. 64-77.

19. Dominique Dinet and Marie-Claire Dinet-Lecomte calculate that only one percent of nuns in France filed a formal appeal of the bull ("Les Appelants contre la bulle Unigenitus d'après Gabriel-Nicolas Nivelle”, in Au cœur religieux de l'époque moderne, Dominique Dinet ed, 2011, (p.317-318). However, they note that a formal appeal was not the best measure of nuns' sympathy with the Jansenist cause which tended to be expressed in other ways and later than the appeal mouvement. (p. 304-305. Françoise de Noirefontaine identified 866 nuns from 81 convents who wrote to Colbert de Croissy and Soanen (p. 21. Homassel witnessed at first hand one group of nuns who did formally appeal; the Franciscan Cordelières of Abbeville signed an appeal on October 3, 1718 which was printed: Acte d'adhésion des religieuses cordelières d'Abbeville à l'appel de monseigneur le cardinal de Noailles (n.p., n.d.).

20. For a lucid account of why the bull was a theological and tactical disaster, unfair to Quesnel and bordering on intellectual dishonesty, see the account by John McManners, Church and Society in Eighteenth-Century France, Oxford, Clarendon Press, 1998, vol. 2, (p. 370-77.

21. Pasquier Quesnel, Lettre du Père Quesnel à M. L'Évêque de Poitier où il se justifie des excès que ce prélat lui attribue dans son mandement du 19 janvier 1716. n.p., 1716, (p. 45-46.

22. Vexations au sujet de la constitution Unigenitus, Bibliothèque de Port-Royal (BO 875), (p. 265-268.

23. Vie de Madame Fontaine in Nicolas Lyon-Caen, Un Roman bourgeois sous Louis XIV, (p. 122.

24. Letter to Soanen, May 30, 1736. Rijksarchief Utrecht, Ancien Fonds d'Amersfoort, 6614 for this quotation and the next.

25. Ibid.

26. "Je crois que nous sommes incapables par nous-mêmes de faire aucun bien qui puisse mériter le salut; et qu'il faut pour cela que Dieu nous donne la volonté et le pouvoir de commencer, de 
continuer et d'achever toutes nos bonnes œuvres. Je crois néanmoins que nous méritons en voulant et en pratiquant le bien, car quoique ce soit Dieu qui nous le fasse connaître et opérer, c'est néanmoins sans contraindre notre volonté; et lors même qu'il lui fait choisir ce qu'il lui a fait connaître être le meilleur et le plus avantageux, il lui laisse toujours la liberté de le rejeter. Et ainsi, il est vrai de dire que, quoique ce soit Dieu qui fasse le bien en nous, c'est nous cependant qui le faisons et que nous ne le faisons que parce que nous le voulons.", Letter of May 30, 1736 to Soanen, Rijksarchief Utrecht, Ancien Fonds d'Amersfoort, fol. 6614.

27. La Vie et les Lettres de Soanen, Cologne, 1750, 2, p. 314-315.

28. Archives Nationales, t 77 1-3, "Profession de foi de Marie Catherine Homassel Hecquet, ma grand-mère", fol. 14.

29. Catherine Maire found that $65 \%$ of the convulsionaries involved with such discourses were in fact women, and moreover they were likely to be of lower class origin. See Les Convulsionnaires de Saint-Médard: miracles, convulsions et prophéties à Paris au XVIII ${ }^{e}$ siècle, Paris, Gallimard/Julliard, 1985, (p. 131.

30. Nicolas Lyon-Caen highlights the importance of Jansenist women in expanding forms of public expression, but points to no Jansenist women who participated in the public space constituted by becoming a published author: “'Il faut qu'un party se sente bien faible quand il accepte et qu'il recherche de tels appuis.' Femmes, jansénisme et publicité à Paris au XVIII siècle", L'Atelier du Centre de recherches historiques [En ligne], 04 | 2009, mis en ligne le 26 juillet 2009. http://acrh.revues.org/1277, accessed February, 18, 2014.

31. See the notice on her by Hervé Savon for a list of her publications in the Dictionnaire de PortRoyal, Jean Lesaulnier and Anthony McKenna ed., Paris, Champion, 2004. The earlier contribution of Françoise-Marguerite de Joncoux (1668-1715) was more substantial and positive, but she died prematurely at age 47 before Homassel became active, and did not sign her publications. An excellent Latinist, in 1699 Joncoux published a translation into French of Pierre Nicole's notes in his Latin edition of Pascal's Provinciales. She collaborated in the publications of Jacques Fouillou and chafed at the restrictions on women displaying their learning. See the entries of Ellen Weaver-Laporte and Régine Pouzet in the Dictionnaire de Port-Royal and of Édith Flamarion in the Dictionnaire des femmes des Lumières, Huguette Krief and Valérie André ed., 2 vols, Paris: Champion, 2015.

32. The commentary that the editors of the clandestine periodical les Nouvelles ecclésiastiques added to accompany two such declarations of faith that it published which had been written by a favorite cousin of Homassel, Jacques Hecquet, the curé of Alléry, illustrates how Jansenist readers appreciated the individualization in such documents: "On trouve toujours dans tous ces actes des tours nouveaux et intéressants qui font voir en combien de manières différentes on peut réclamer et déposer contre la fatale bulle", July 16, 1744, (p. 114.

33. Archives nationales, Minutier central, étude LXXVII, 297, July 7, 1764.

\section{ABSTRACTS}

Following Saint Paul, women were excluded from public religious roles and expected to eschew theology for affective devotional practices. The article explores the gender bind this placed on Jansenist nuns and laywomen, who felt compelled to declare their stance, by focusing on MarieCatherine Hecquet. She was pried from a convent and browbeaten into marriage. It compares her 
to her seventeenth-century models, the Port-Royal nuns in the formulary disputes, and to eighteenth-century nuns who protested against Unigenitus. It examines two kinds of "I" portraits of these women: professions of faith and autobiographical accounts of their persecutions which reveal acute theological learning.

Suivant Saint Paul, les femmes ont été exclues des rôles religieux publics et on attendait d'elles qu'elles évitent la théologie au profit de pratiques de dévotion affectives. L'article explore la contrainte de genre imposée aux religieuses et aux laïques jansénistes, qui furent forcées de déclarer leur position et détaille le cas de Marie-Catherine Hecquet. Elle fut retirée de force d'un couvent et contrainte de se marier. L'article la compare à ses modèles du XVII ${ }^{\mathrm{e}}$ siècle, les religieuses de Port-Royal lors des disputes du formulaire et aux nonnes du XVIII siècle qui protestèrent contre la bulle Unigenitus. Il examine deux sortes de portraits à la première personne: professions de foi et récits autobiographiques des persécutions marqués par une appropriation des savoirs théologiques.

INDEX

Mots-clés: Homassel Hecquet (Marie-Catherine, interdiction de saint Paul, profession de foi, femmes jansénistes

Keywords: Homassel Hecquet (Marie-Catherine), jansenist women, unigenitus, Pauline interdiction, profession of faith

\section{AUTHOR}

THOMAS M. CARR JR. 